HStud 22 (2008) 1-2, 9-29

DOI: 10.15566/HStud.22.2008.1-2.2

\title{
DOES FOLK DANCING MAKE HUNGARIANS? TÁNCHÁZ, FOLK DANCE AS MOTHER TONGUE, AND FOLK NATIONAL CULTIVATION
}

\author{
MARY N. TAYLOR \\ Hunter College, City University of New York, NY \\ USA
}

\begin{abstract}
This paper, based on participant research amongst folk revivalists, interviews with cultural managers, and extensive archival research, discusses the táncház (dance house) folk revival movement as the actualization of interwar efforts of "folk national cultivation" in Hungary. By putting the dance house in relationship with interwar folk critiques, the paper illustrates both continuities and discontinuities between them, most notably in conceptualizations of the relationship between the ethical or political roles of such critiques and of the folk itself. The paper argues that folk critiques, now and then, can play an important role in state formation by reproducing the folk and acting to secure its citizenship. Nevertheless, how the folk is defined is historically determined, as is the kind of citizenship entailed. Since folk national cultivation is premised on the idea that Hungarianness is produced through engagement with the folk and its traditions, the historical approach of this paper problematizes this process.
\end{abstract}

Keywords: Táncház, Dance House, Folk Revival, Hungarianness, nationalism, state formation, social movements, citizenship, ethical cultivation

In 1939, just as Hungary began, with the help of Germany, to annex a chunk of the neighboring territory forfeited nearly twenty years before at the end of World War I, István Györffy, "the father of Hungarian ethnography," published a pamphlet originally written in 1938 as a memo to the Ministry of Religion and Education entitled Folk Tradition and National Cultivation (A néphagyomány és a nemzeti müvelödés). The text prescribes a program for Folk National Cultivation (Népi-Nemzeti Müvelödés), suggesting ways in which the cultural patrimony of the folk, the oppressed agrarian classes who made up two thirds of the population and who in Györffy's understanding made up the most Hungarian stratum of society, can be made that of all Hungarian citizens through the incorporation of folk (népi) culture into everyday life. ${ }^{1}$

This was not the first (or the last) time that Hungarian intellectuals would pursue such projects with the aim of cultivating Hungarianness. The nation-state aspirations of a Hungary subsumed within the Habsburg Empire had encouraged 
magyarization (Hungarianization) policies, especially in the period after the Compromise of 1868, which resulted in the establishment of the Dual Monarchy. Such policies cajoled and coerced the multiethnic population of Hungary to "become Hungarian" by assimilating to the linguistic nation, or "sprachsnation" (Kann and David 1984). This language-based production of Hungarianness was influenced by the Romantic thought of Johann Gottfried Herder, who, countering the enlightenment idea that language is a tool for communication and thought, argued that national languages are historically produced treasuries of thoughts specific to any given nation and as such are "both representative of and constitutive of the volksgeist" (Taylor 2006; see also Burger 2003). ${ }^{2}$

Györffy's plan synthesizes many of the ideas espoused by folk oriented projects acting in the rich and complex sphere of Hungarian civil society in the interwar period. In a twist of the earlier romanticism surrounding language, composers-ethnomusicologists Béla Bartók and Zoltán Kodály advocated that musicians master folk music as a "mother tongue.” In one example Bartók wrote,

in this case, the composer has completely absorbed the idiom of peasant music, which has become his mother tongue. He masters it as completely as a poet masters his mother tongue (Bartók 1976, 343-344).

Drawing on this idea, Györffy writes in his pamphlet that Hungarian folk song is the other expressive form of the Hungarian language (1993, 24). Folk music here takes on the significance and cultivating power that language had had in the period mentioned above, and Györffy suggests that it needs the protection and care afforded to the language itself.

In the interwar period a group of népi, or so-called "populist," writers promoted similar practices of folk cultivation, inspiring a much broader "népi movement" that enacted the idea in myriad ways. ${ }^{3}$ This body of people and projects occupied with the folk, folk culture, and the nation was heterogeneous and boundaries between groups were porous. "Village visiting" (so-called falujárás) represented a central activity intended to promote familiarity with folk practices and the village way of life and empathy for the villagers themselves. Populist writers and their followers debated amongst themselves over whether to remain a spiritual/intellectual movement, or whether to enter politics proper. Many saw it as their responsibility to bring the spirit of the movement to "every social and political frame" (Borbándi 1989, 255-256).

While Eric Hirsch (1997) has used the term "folk nationalist" to describe all those in the interwar period who were preoccupied with the folk, in truth successive interwar movements recognized populists both as a threat and a potential source of legitimacy. Government and populist interests converged in some folk oriented activities, especially in the late 1930s and during the war, reflecting both 
populist commitment to permeate the entire political spectrum and government efforts to harness their intellectual influence. While ideological and practical tensions abounded, the extent to which the government adopted the language of folk national cultivation is reflected in the following. In 1940, while praising the Bouquet of Pearls folk dance movement, Prime Minister Pál Teleki was quoted as saying

I have approached my allies... our greatest task is that we keep the Hungarian spirit (lelki) in this nation, that we teach it to think in Hungarian. Not to wander the world as a beggar (koldus), but rather to go on its own legs, to speak Hungarian, to sing in Hungarian, to dance in

Hungarian. Because one who does that, also thinks in Hungarian (Teleki in Pálfi 1970, 124).

Despite the obvious emphasis on practice, it is notable that Teleki did not use the term nép here, using nation instead. One notable convergence of populist and government aims was their shared concern for the ethnic Hungarians living across the borders set in 1920. Not needing to explain further, Györffy simply writes, "the protection of folk tradition is most important in the occupied territories" (1993, 52).

In this paper I approach the text of Györffy's pamphlet as both a theory of collective memory and a plan for its reproduction. Asserting that the seed of Hungarianness does not lie in one's genealogy or name, he wrote, "Hungarianness is not a question of the body, the blood, but of the soul" $(1993,77)$. He believed that Hungarianness, a Hungarian soul, could be cultivated through specific practices originating with the folk. I aim here to use Györffy's theory of collective memory and plan for the reproduction of Hungarianness as a starting point for the examination of the táncház (dance house), a folk revival that emerged in Hungary in the late socialist period the central practice of which is the mastering of the paradigm of folk dance as social dance and its use in everyday life, what I term folk dance as mother tongue. Doing so will not simply illuminate this case in Hungary, but also, I argue, help us think through the historical tensions in the relationship of ethics and politics and conceptualizations of the terms nép (folk) and népi (of the folk). Indeed examining the relationship of nation-building and state formation in its historical dynamism should be an important avenue for the study of nation-building everywhere. The important lens of state formation, what I take to be the process of legitimation and the elaboration of social identities unfolding from the institutionalization, definition of, and practice of citizenship, allows us to understand the state as a 'form of rule or ruling,' thus focusing our attention on how rule is accomplished through dynamic relationships rather than on a state that rules (Corrigan 1994, xvii). ${ }^{4}$ 
By exploring the ways in which the dance house revival represents the actualization of Györffy's program, I illustrate the weakness of his implicit assumption that there is a timeless Hungarian soul that can be cultivated or a timeless folk that can be its source. I will show how, while folk critiques rely on the folk, a concept that like the German "volk" may be employed with class or ethnic connotations, state formation processes in 20th century have contributed to a collective memory that understands the folk in a primarily ethnic sense.

A note on definition is called for here. Györffy, populist writers and activists, and the dance house itself are bound together in this paper by their attention to the folk. Rather than calling them populist movements, the favored term of translation for the népi movement of the interwar period (but a term never to my knowledge applied to the dance house), I refer to these folk oriented projects as folk critiques. ${ }^{5}$ I suggest that these movements function to do two things. First, through folk based critiques they reproduce and reify their object, the folk. Second, by engaging in such a critique, participants construct themselves as Hungarian. Given the folk's age-old role as seed of the Nation, folk critiques unsurprisingly play an important role in the production of a sense of the nation. Yet less acknowledged has been their role in state formation. This paper thus notes a consistent preoccupation with the nép (translated here as folk) and labeling of movements as népi (of the folk), while their conceptualizations flux. In other words shifts in the meaning of these terms, which reflects broader changes in citizenship regimes, are central to this analysis.

In what follows I will explore the links and ruptures between folk critiques of Györffy's era and the dance house revival. I will establish Györffy's project of folk national cultivation as both a theory of collective memory and a plan for its reproduction, embedding it within the literature on collective memory, before introducing the dance house as an actualization of the plan. I will then qualify this status by providing a historical contextualization of shifts in both conceptualizations of the relation of this ethical project of collective memory production and the political sphere and of the very meaning of the term nép (the most immediately available English translation of which is folk).

\section{Collective Memory: History, Sense}

Györffy tells us that while the use of writing allows us to pass intangible customs on to new generations, "if they do not remain in the memories of the living, they will become lifeless traditions that no longer have the powerful life directing force that living traditions or customs have" $(1993,7)$. In this sense, his definition of collective memory is very similar to that of French sociologist Maurice Halbwachs, who took pains to distinguish collective memory from historical 
memory and history as "the active past that forms our identities" (Olick and Robbins 1998, 111). Both Györffy and Halbwachs conclude that collective memory relies on material practices. Yet Halbwachs' attention to historical change challenges Györffy's assumption that a timeless and unique Hungarian soul can result from this perpetuation of form.

Halbwachs proposed collective memory to be a dialectical process resulting from the interaction of past and present. By applying interpretations influenced by contemporary circumstances to institutionalized material practices, he argued, groups produce a picture of the past $(1992,101)$. While such institutionalized practices may go virtually unchanged over time, giving an appearance of unbroken continuity, interpretations continue to change, renewing the contemporary relevance of collective memory $(1992,117)$. Other thinkers have also contributed to a nuanced understanding of the historical production of collective memory by looking at how such institutionalized practices are connected to the senses.

Arguing that the "National thing" is an effect of belief, Slavoj Zizek furthers that it is enjoyment, "materialized in a set of social practices and transmitted through a set of national myths that structure these practices," that provides its ontological consistency $(1993,202)$. Charles Hirschkind takes the relationship of collective memory and the senses even further. Offering an approach to "the relation between sensory experiences and traditional practice" $(2001,628)$, he suggests that practices of "ethical self-discipline" can serve to sediment emotions in practitioners "in such a way to incline them toward moral action" (2001, 631). Examining the case of cassette sermon listeners in Egypt, Hirschkind asserts that the link between listening and sense is not simply "established metaphorically, but also through discipline, the training and inculcation of sensory habits," including bodily dispositions (2001, 628). Hirschkind's intervention connects senses and sensibility by examining how disciplinary practices may inform emotions and judgments. He thus shares with Györffy the idea that the individual hones an ethical sensibility by engaging in practices institutionalized and given meaning to by a group. Finally, providing a nuanced view of collective action, Alberto Melucci (1988) argues that "frameworks of sense" underlie and inform social movements, thus allowing us to perceive a relationship between the cultivation of ethical dispositions and state formation. This relationship will be returned to later in the paper.

Györffy and his contemporaries believed that the cultivation of Hungarianness through folk practices would lead to empathy for the folk. In this view, such empathy would affect social relations and consequently the social structure itself. The dance house folk revival, which arose in the 1970s and is still active in Hungary today, represents in many ways the actualization of Györffy's program. Attention to this népi movement/folk critique that arose over three decades after the publication of Györffy's pamphlet illustrates the historical, political, and eco- 
nomic dimensions contributing to the production of collective memory. ${ }^{6}$ Indeed, the very fact that dance house incorporates the use of folk practices in everyday life and has a strong relationship to populist current helps to illustrate the weakness of his assumption that there is a timeless Hungarian soul or a timeless folk that can serve as its source. On the other hand, Györffy's plan does prompt us to consider how the production of a certain collective memory, or ethical cultivation, through dance house practices can influence political outcomes, affecting access to or definitions of citizenship. We witness in dance house a reproduction of a sense of Hungarianness based on the reproduction of its source, the alleged folk. Yet we also see that the folk has come to constitute something quite different than the conception of it that took form in interwar Hungary. To understand how this came about, we need to place Györffy's program in historical context.

\section{The Nép in the Interwar Period}

Györffy is no forgotten ancestor. Indeed, his pamphlet was republished by the István Györffy Ethnographic Association in 1993, while in 1991 ethnographer Bertalan Andrásfalvy, Minister of Culture for the first democratically elected government of the postsocialist era (Magyar Demokrata Fórum, or Hungarian Democratic Forum), published a lecture entitled "István Györffy's Program for the Spread of Elements of Folk Cultivation Throughout Society." Seeking to "translate" Györffy's use of the term "middle class" (középosztály) into "today's usage," Andrásfalvy writes: "in 1939, one third of the population counted as middle class" $(1991,159)$. Stressing that the term should be understood in "the cultural, not social sense," he counts within that group those who had "outgrown folk traditions" and made European culture their own through schooling and books. Defined in opposition to the middle class, he writes, was that two thirds of the population, the folk, that lived with folk traditions or was beginning to leave them behind, but who did not take part in Europe's common culture. These were mostly peasants. Andrásfalvy's insistence on the cultural sense of the term middle class at the price of its social sense obscures important differences in Hungary's social constitution and political economic circumstances between 1939 and 1991.

Györffy and his populist associates used this same statistic to discriminate between these two classes of Hungarians. However, they did not stop at noting "cultural differences," recognizing in addition the limitations on citizenship experienced by the folk. ${ }^{7}$ By 1928 Hungary had been dubbed "Három millió koldus országa," the land of three million paupers, in reference to the rapidly proletarianizing stratum of manorial servants and their families, agrarian workers, dwarf-holders, renters, and sharecroppers, who made up a third of the total population and 67 percent of the peasant population (Borbándi 1989, 58). ${ }^{8}$ Secondary 
education was indeed a rare privilege for this group, for large landholders did not encourage the schooling of their servants, believing that "knowledge and culture will ruin them" (Borbándi 1989, 63). Landless and unrepresented in the political sphere, this class carried the more privileged classes on its shoulders (Taylor 2008). Furthermore, in this period the term middle class was used to refer to the officer and bureaucratic classes derived from the nobility, whose historical domain was the state apparatus (Borbándi 1989, 33, 48; Mócsy 1983). ${ }^{9}$ Indeed, the governments of the Horthy era ruled with the conviction that only the "historical classes" (the aristocracy, the middle nobility, the land-holding gentry, and the bureaucratic, military officer, and intellectual layers that had developed from within them) should participate in the political sphere, for it was these groups, which together comprised the middle class, that would assure the country would remain Christian and National (Borbándi 1989, 37). Thus in a holdover from the feudal usage of "nation," meaning those with political rights, the term nation (nemzet) was associated with a regime that protected the property interests of the Catholic church and the aristocracy (Borbándi 1989).

In the period in which Györffy wrote, then, the terms middle class and folk were not merely the cultural categories that Andrásfalvy stresses. They were descriptions of social strata. This is why many people identifying themselves with the cause of the folk did not stop at preserving, spreading, or validating its culture, but also agitated for land reform and voting rights in its favor. Not all activities focused on the folk stressed social justice, however. Indeed, the Bouquet of Pearls Movement and the boy scouts troupes that learned folk traditions and danced folk dances (the so-called regös scouts, who were influenced by the movement that laid emphasis on "village visiting," mentioned earlier) can hardly be considered progressive. Yet in the Protestant folk high schools (népföiskolák), the more overtly political Peoples' Colleges (Népi Kollégiumok), the 1932 March Front mobilization, and the National Peasant Party social justice was a dominant theme. ${ }^{10}$ In his book The Hungarian Populist Movement, Gyula Borbándi notes that in the interwar period those actually labeled populist (népi) were not simply interested in using or preserving elements of folk culture. The use of folkloristic elements might have qualified a writer's work as népies (folksy), Borbándi writes, but such writers could not be considered népi (populist) because they "did not tie [their] representations and images of the village to a demand for the transformation of society and held [themselves] distant from "radical political movements"" $(1989,133) .^{11}$

It might be difficult to secure Györffy's role within the "népi movement," which itself remains a slippery category. While he appears in Borbándi's book as an important figure and his connections to the Peoples' Colleges are well documented, he also had close ties with the far from radical Bouquet of Pearls folk dance revival movement. Yet the fact that the exhibition he organized at the Insti- 
tute for Regional and Folk Research (Táj és Népkutató Intézet) highlighting the oppression and poverty of the folk was shut down because it was an affront to the government and the large landowners that supported it (Borbándi, 239-240) ${ }^{12}$ shows that he did not turn a blind eye to the social conditions of the folk. ${ }^{13}$

Divorced from the social and political platform pursued by populist activists, attention to the folk could be found in the efforts of the interwar governments to quiet, tame, or co-opt such critical forces to its "Christian national" program, which favored rule by the so called "middle class," made up of the military and bureaucratic classes derived from the nobility. One example of this was The New Spiritual Front policy pursued by Prime Minister Gyula Gömbös, designed to enlist influential intellectuals concerned with the folk to the Christian National cause. As the imminence of the permanent loss of much of the territory lost at Trianon and the threat of German occupation became more possible with time, these various approaches may have become less distinguishable, but there is no doubt that occupation with the folk in the interwar period was born of the continued social and political oppression of the agrarian classes. ${ }^{14}$ Disembedded from this historical context, Györffy's program loses its connection to the interrelated social and cultural definitions of the folk in the first half of the 20th century. Here cultural validation was recognized as a cohort of social justice. Ethical cultivation, the production of Hungarianness through the engagement in folk practices, was thought to lead to empathy for the folk, the source of Hungarianness. This empathy, in turn, was to lead to the transformation of society.

\section{Ethical Cultivation, Politics, State Formation}

While populist activists of the interwar period pursued land reform and the franchise in tandem with cultural validation and the production of Hungarianness through folk practices, it is important to point out that a tension did exist within the movement concerning the proper sphere of action. Populist writers disagreed amongst themselves over whether the movement should enter politics proper. Seeing it as their responsibility to bring the spirit of the movement to "every social and political frame," many asserted that this should remain a spiritual/intellectual movement (Borbándi 1989, 255-256). Populist writer Géza Féja concluded in his article entitled The March Front that it should remain "a sociological and literary movement guiding the world view, because in today's politics things would only become stagnant" (Féja, in Borbándi 1989, 257). For populists, then, opposition

was not simply a political matter. On the contrary, many opposed engaging in the formal field of politics in what they saw as a corrupt regime, working primarily in the spiritual sphere. Even when more overtly political manifestations arose, most notably the March Front mobilization and the National Peasant Party, populist ac- 
tivists insisted that their work lay in the spiritual sphere. This conviction was only confirmed by the compromised position in which the Peasant Party found itself after the war, which I will consider later in this article.

Scholars have pointed out that conceptualizations of spheres of action are tied with political and economic circumstances of state formation. Partha Chatterjee (1986) suggests that anticolonial nationalism creates its own sphere of sovereignty within colonial society long before engaging in a political battle. This process establishes an opposition between the "outer sphere," the domain of statecraft and formal politics, and the "inner sphere," comprised of that which "marks cultural identity." Rather than seeing this dichotomy as unique to the colonial situation, we might see it as reflective of situations in which limitations on citizenship prevail for certain classes of people under conditions of coercive political dominance. Chatterjee's description of the Bengali case is reminiscent of the German context to which both Terry Eagleton and Norbert Elias point, the context in which the idea of Kultur was posited as a response to that of civilization. Elias suggests that this formulation resulted from the "long political impotence of the German bourgeoisie combined with the late unification of the nation" $(1978,27)$. He writes,

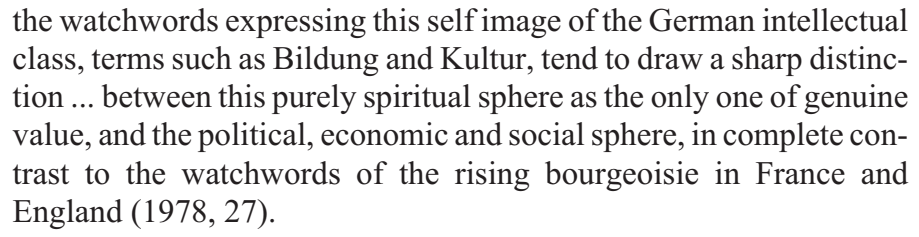
class, terms such as Bildung and Kultur, tend to draw a sharp distinction ... between this purely spiritual sphere as the only one of genuine value, and the political, economic and social sphere, in complete contrast to the watchwords of the rising bourgeoisie in France and England (1978, 27).

As social conditions changed and characteristics of the bourgeoisie expanded to become national characteristics, this distinction, which had begun as a class distinction, became a national distinction (Elias 1978, 31).

The political and social situation in interwar Hungary shares some qualities with this case. While formal citizenship had been guaranteed since the 1840's, there were nevertheless practical limits to citizenship. The un-propertied agrarian classes remained unrepresented in the political sphere, with only limited access to education, progressive political parties were curtailed in their activities and intellectual production was threatened with censorship (Taylor 2008). In places in which "political dominance assumes... more openly coercive forms," as in the case of Germany in the 18th century (or, we might add, interwar or socialist Hungary), the response might appear, writes Eagleton, as "aesthetic counter strategy a cultivation of instincts and pieties over which such power rides roughshod" (Eagleton 1990, 27).

The more overtly political activities of the populist movement have been obscured partly due to their strong orientation toward the spiritual sphere, but very 
likely also due to the role populist activists played in the transition to socialism. With increasing censorship and the increasing difficulty of obtaining permits for their activities, the movement was faced with the choice of founding a political party or fading away. In 1939, with Germany now Hungary's next door neighbor, far right parties fared well in local elections (Borbándi 1989, 321). A circle of populist writers and their agrarian supporters formed the National Peasant Party, which, like the Communist Party, was illegal until 1945 (Borbándi 1989, 326). ${ }^{16}$

Not all populist writers agreed with the formation of the party, many argued that no single party could represent the movement (Borbándi 1989, 325).

Part of the resistance (the Hungarian Front) during the war, The National Peasant Party coalesced with the Communist Party, The Social Democratic Party, the Civic Democratic Party, and the Smallholder's Party in The Hungarian National Independence Front, formed in 1944. While the overwhelming majority of votes in the 1945 elections were for the Smallholder's Party, the Communist Party was able to play "a decisive role" through this coalition (Hanák 1991, 214). The Communist Party further engaged in a series of purges and de-legitimations, aided by its merging with the Social Democratic Party in 1948 (Hanák 1991, 216). Despite having received only a small proportion of the votes, the National Peasant Party secured the Ministry of Public Works (Péter Veres, later József Darvas), the Ministry of Defense (Veres), and the Ministry of Agriculture (Ferenc Erdei) (Borbándi 1989, 445-447). While the Party would soon be dissolved along with other parties, the fact that many populists had been left-leaning meant that a number of them still continued to occupy positions of influence during the Stalinist era. Others suffered various levels of persecution. ${ }^{17}$ Most, however, found themselves in the myriad positions of cultural management occupied by intellectuals.

Beyond those few Peasant Party politicians who worked for the regime and the brief reappearance of the party as the Petôfi Party in the months of the 1956 Revolution (when the decision was made not to allow such "collaborators" a leading role) (Borbándi 1989, 467), populist activists sought to continue their work in the spiritual sphere. Indeed, the image of the populist movement resonant today portrays them as oppositional to and oppressed by the Communists. In any case, while formal populist institutions were dispersed in 1948, populist influence lived on under changing political and economic circumstances.

\section{The Dance House Movement: Practicing Folk Dance as Mother Tongue}

In the 1970s the dance house movement arose from the interaction of state socialist cultural policy, the activities of populist cultural managers, global trends in folk revival, and spontaneous youth movements (Martin 1981; Striker 1987, 1989; Halmos 1994, 2000; Ronstrom 1998; Taylor 2008). The emergence of the 
dance house revival was dependent on the convergence of the interest among "beat" (rock and roll) musicians in village instrumental music and that of performing folk dancers and choreographers in moving beyond borrowing isolated motifs to learning entire dances. Revivalists sought to become familiar with the internal logic of dances embedded in the social environments of village dance events, or dance houses. Modeled after dances, or balls, traditionally organized by adolescents in the Transylvanian village of Szék (referred to as táncházak or dance houses), the first Budapest dance house event was an attempt by the performing folk dancers to transcend staged choreography and competition and engage in Hungarian folk dance as social dance (Halmos 2000).

To be successful, however, these events required a live band able to play entire suites and participants able to dance entire dances and dance suites. In order to spread beyond the narrow layer of performing dancers and accompanying musicians, the movement required institutionalized pedagogical technologies. The solution was to provide dance instructors at each event to teach dance forms to newcomers and help dancers acquire folk dance as a "mother tongue," that is, to gain such familiarity with the rules of the dance that individuals would be able to innovate within their framework appropriately. Because the dance house was organized around teaching the entire dance suites of particular villages or regions, this mastery of the folk dance as social dance and its use in everyday life also meant an intimate knowledge of the traditions of particular places, the majority of them in Transylvania. Much like "village visitors" (interwar ethnographers and enthusiasts of the folk who traveled to villages to familiarize themselves with "folk culture"), dance house goers visited Transylvanian villages in droves, hoping to gain first hand knowledge and in the process making personal connections.

In its longevity, breadth of popular appeal, insistence on the systematic integrity of folk dance and folk music as complex social and aesthetic forms, pedagogical emphasis on folk dance as mother tongue, and success at getting urban Hungarians to visit villages (especially in the territories lost), the dance house movement appears as the realization of Györffy's plan. By all means, through its technologies, this movement not only introduced folk practices to a broad spectrum of Hungarian citizens who had not been exposed to them at home or in villages, but also helped them integrate them into their everyday lives as a regular social activity. ${ }^{18}$ To have achieved Györffy's goal, however, this engagement in folk practices must also have contributed to the Hungarianness of participants. How might we evaluate its success on this front, when Györffy insists that external form is not enough? Recall that, according to him, even a person with pure Magyar pedigree does not have a "Hungarian soul" if all he does is "act like a Magyar" (magyarkodik) (160). Recall too that populist activists in the interwar period believed that the adoption of folk practices would result in empathy for the folk, which in turn could lead to social justice. Györffy and his fellow populist activists thus pur- 
sued two interrelated goals. They wanted to bring social justice to the folk by making the entire nation more Hungarian through the adoption of folk practices and the practice of "village visiting." Finally, recall that the folk was not oppressed as Hungarians per se, but as the lowest stratum in a feudal-like social structure. If we accept that "Hungarianness" can be measured by sympathy for the folk, itself reflected in changes in the political sphere, then we must examine the consistent conceptualization of the dance house as apolitical by its participants in relation to the changes in the meaning of folk (nép) over time. While the terms drawn on to define the movement have been attached to political projects in the past, for dance house revivalists, "the people" have become "the ethnic folk."

Unlike the many populist activists of the interwar period, while they too identify themselves as "népi" dance house goers as a group have never been comfortable with the idea that dance house is political. Furthermore, despite their own tendencies to do so, dance house goers are apprehensive about the use of the term movement to describe their activities. Noting its use by the socialist administration in reference to political movements instigated and maintained by the Party itself (such as the "workers movement" or the "youth movement"), they suggest that the term represents a centralized and political initiative.

In interviews conducted during fieldwork in 2004, dance house goers and organizers stressed to me the non-ideological character of the movement. Arguing that it is simply the love of folk dance and folk music that brings them together, participants insist that there is no ideological thread that unites them. Despite this, many expressed that dance house goers share an ethical worldview. Indeed, in interviews, dance house goers described dance house as a community; a "virtual community" that comes together at certain moments (like the Dance House Meeting); a "virtual circle... which is not definable but rather a feeling - if a person says now that they are, 'I am a dance house goer (táncházas)." The ideas that the dance house had an oppositional quality under socialism and that it teaches people important values were frequently expressed. Such a situation suggests that we take a nuanced approach to social movements, aided by our understanding of the historical production of collective memory.

Lamenting the conceptual fragility and overuse of the term "movement" in explaining the "social nature of collective action," Alberto Melucci suggests that in a number of social movements what collective actors have achieved is "to practice 'alternative definitions of sense" "by creating "meanings and definitions of identity which contrast with the increasing determination of individual and collective life by impersonal technocratic power" (Melucci 1988, 247). It is the networks made of those who share such "frameworks of sense" that make mobilizations possible, he argues, "rendering them visible in a punctual manner at moments when confrontations with public policy emerge" $(1988,248)$. Yet, stressing qualities quite different from those of the "rational actor" favored by many social 
movement theorists, Melucci writes, "within these networks there is an experimentation with and direct practice of alternative frameworks of sense, in consequence of a personal commitment which is submerged and almost invisible" $(1988,248)$. While individuals engage in dance house activities for myriad reasons, they are bound together by a framework of sense produced, I argue, through the practices of dance, etiquette, sociable conversation, and village tourism: in the associative space of dance house events.

This framework of sense produced in the associative space of dance house events may congeal, I argue, into a fragile and contradictory "community of sense" in moments of collective action beyond participation in the social event. ${ }^{19}$ It is thus that this shared framework of sense extends to the ways in which people act outside of the dance house setting. I find evidence that dance house participants, united by activities and practices promoting the perpetuation of 'folk tradition' in everyday life, share ideas about nation and citizenship on which they act in their private and public lives. While dance house goers do not agree on everything, it is clear that the associative events of dance house are socializing events, a characteristic that most dance house goers would acknowledge of the "original" village dance house on which revivalist events are modeled.

\section{Submerged Senses, Sensibilities}

How do we get, however, from a shared framework of sense to something like a political sensibility? Recall that Halbwachs argued that collective memory is produced through the interaction of institutionally preserved practices and meaning ascribed to them, influenced by contemporary circumstances, including available ideologies and political economic conditions. In the 1940s Györffy's students László E. Kovács, and Gyula Ortutay suggested that Györffy's "nemzetnevelő" (nation cultivating) prescription should be followed and vowed to take on this responsibility (Balassa 1993). ${ }^{20}$ But from the 1950 s on it was cultural managers more than academic ethnographers who pursued the work of népi (people's, folk) cultivation. In his assessment of the application of Györffy's ideas, Bertalan Andrásfalvy points out that the Népmúvelési Intézet (Institute for People's Culture) sponsored the so-called hagyományörzö (tradition-keeping) dance ensembles in the villages.

Founded as the Népi Múvelődési Intézet (Institute for Folk Culture) in 1946 by populist (népi) writers Gyula Illyés and László Németh, with the support of the Szabadmúvelődési Tanács (Council for Free Cultural Cultivation), this Institute was funded by the Socialist state from 1950 onwards (Taylor 2008). Its direction was strongly effected by populist (népi) employees and directors, including Elemér Muharay, György Martin, and Iván Vitányi, who continued to have a 
strong influence. The Institute did much more than support the village tradition-keeping ensembles, however. It was the main resource center for performing folk dancers, and the home to the Magyar Állami Népi Együttes (Hungarian State Folkdance Ensemble). Furthermore, folk dance and folk music collections were made by its employees and housed in its archives. Beyond this, a main task of the Institute was to guide associative life and to provide resources for cultivating institutions (such as the network of culture houses) and associative activities (usually held within them) (Taylor 2008). ${ }^{21}$

It is no coincidence that the Institute lent strong support to the infant dance house revival. In fact some call long time employee and folk dance scholar György Martin the "father of the dance house" because he introduced key musicians and dancers to one another and encouraged them to revive the village social dance environment. At the institute, Iván Vitányi, a populist (népi) since his youth, produced literature on the dance house as a realization of populist goals (1972). He became director of the Institute in 1973, and by 1976 plans had been made for a "dance house leader" course modeled on the "club leader" courses taught in previous years to facilitate club activities in the culture houses (Taylor 2008). His language was tempered by the socialist milieu, but was not at odds with his commitment to social democracy. He claimed that the formation of communities was at the heart of folk art.

"At the beginning," said Ferenc Sebő, musician and key actor in the emergence of the dance house in a 1976 interview, "we were immediately preoccupied with what folk art is about; that it creates community and spreads the basis of cultured recreation (szórakozás) and awakens the demand for more and better too" (Sebö, 1977, 5). Like folk, community is a malleable term. While youth at that time expressed the desire to counter what they saw as the alienation of socialist culture, as long as the community form was borrowed from "the folk" it was unclear whether such a community could be created or only continued. While he defended the dance house revival against charges of nationalism, in Vitányi's view, folk dance as a community-forming activity relies on the fact that it is practiced by a community. The folk was taken, unproblematized, as that community.

Personal accounts of dance house goers show that their varied and idiosyncratic ideas about dance house are influenced both by historical and contemporary discourses. Many use the ideas of the populist movement and Györffy without referring to them, especially when speaking of its apolitical but cultivating role, while some point explicitly to interwar populist activists. Influential choreographer and key figure in the first Budapest dance house events, Sándor Tímár, for example, cites Györffy in his 1999 book In the Language of Folk Dance, in which he links Györffy's program with "the right to speak one's mother tongue," a right he believes should be extended to dances (Tímár 1999, 7). Dance house goers 
very rarely acknowledged to me, however, the broader political project that populist activists pursued in the interwar era, emphasizing instead the apolitical ethical role that those labeled népi were known for in both the interwar and socialist eras. Despite the breadth of interpretations of what dance house is or does, most dance house goers at one point or another associate dance house with some kind of ethical outcome.

\section{Hungarian Soul?}

Now we must return again to the question at hand. If collective memory, specifically, a "Hungarian soul", can be produced and reproduced through the incorporation of folk practices into everyday life, how might we evaluate its content? The goal of those who espoused "népi nemzeti múvelődés" (folk national cultivation) was to produce a framework of sense through cultural innovation, the production of models of behavior and social relationships that enter into everyday life (Melucci 1988, 247). Yet Melucci further argues that it is the networks made of those who share such "frameworks of sense" that make mobilizations possible, "rendering them visible in a punctual manner at moments when confrontations with public policy emerge" (1988, 248). Györffy and népi activists hoped to cultivate in Hungarian citizens a sympathy for the folk and its practices not simply to create a community in itself, but because they hoped the creation of this community of sense would result in a transformation of the social system. We know that in dance house a preservation of folk form is achieved, but what about respect or empathy for the folk? What about social justice? What about the transformation of society?

If we take the folk to be best represented by Hungarian minority villagers in Transylvania, as many dance house revivalists do, then we might take as evidence the fact that most of those with whom I spoke asserted their responsibility to vote yes on a 2005 referendum calling for Hungarian citizenship rights for ethnic Hungarians in the neighboring countries, most of whom live in Transylvania. While the referendum was nullified by low turnout, dance house goers' expression of responsibility toward Hungarians living outside of Hungary may have translated into a significant proportion of the $51.5 \%$ of the population that went to the polls $(35 \%)$ who voted yes. Indeed we might witness here a framework of sense manifesting as a mobilization. But if we recognize this "Hungarian soul" thus, then we are tempted also to examine the contemporary meanings of the word folk and their relationship to political and economic circumstances.

Györffy wrote in a period characterized by the cataclysmic loss of two-thirds of Hungarian territory to the neighboring countries. While the loss of this territory made the polity more homogeneous that it had been before, it also had two other consequences that are important in this context. The first was discrimination faced 
by ethnic Hungarians under their new governments. The second was a demographic change on a massive scale caused by the change of borders and the resultant influx of refugees to Hungary. This influx of mostly middle class landowning Hungarians meant that those who remained beyond the borders were those who could not afford to leave, in other words those who comprised the folk. In Hungary the continued feudal-like structure of political and social life pursued by the Christian National government, in which displaced nobility cum middle class were overrepresented, was justified by the need to support these "immigrants." The size of the state apparatus, the historical role of which had been to employ the nobility, remained the same in a polity reduced to a third of its former size (Mócsy 1983, 185-186; Taylor 2006). Yet the loss of the territories was considered unfair by all, and both the government and populist activists were concerned with reproducing Hungarianness in Transylvania.

In the Socialist period that followed Communists attempted to co-opt the term folk to mean "the working classes" or "the people." "2 While the Hungarian word nép, like the German term Volk, had class connotations, it was strongly associated with the agrarian masses, and Communists were not able to wrest the term from its romantic and ethnic sense. With political engagement forbidden and social citizenship guaranteed, if differentially, the populist focus on social justice shifted toward those ethnic Hungarians oppressed in Transylvania. Why was this the case? First, processes of uneven development (collectivization included) guaranteed that agriculture was modernized more slowly in Transylvania than in Hungary. This meant that isolated Transylvanian villages retained "traditional" features, while Hungarian villages experienced rapid change. Second, ethnic Hungarians in Romania were subject to oppression, especially under the fiercely assimilationist policies of the Ceaușescu regime beginning in 1965 (Brubaker et al. 2006; Chen 2003). Third, beginning in that same period, Hungary "enjoyed" a kind of cultural thaw resulting from the legitimation policies of János Kádár, who came to power after the 1956 Revolution. In the later years of Socialism the Hungarian government allowed expressions of solidarity, culminating in massive protests in 1988, with Transylvanians as a kind of escape valve (or legitimation device) in the place of domestic issues (New York Times 1988; see also Kürti 2001). Finally, as Slavoj Zizek (1993) notes, conceptions of Gemeinschaft and Gesellschaft were united under the oppositional or "ethical civil society" (Renwick 2006) of the socialist period, when occupation with the folk helped to establish Communism as foreign, simultaneously strengthening the idea of the nation, and the ethnicification of the folk.

Using a lens of state formation and a nuanced approach to social movements, I have illuminated the continuities and ruptures between Györffy's plan for folk national cultivation and the dance house movement that arose over 30 years later, and contextualized the meanings that the concept of folk inhabits at different his- 
torical conjunctures. Dance house represents the realization of Györffy and his contemporaries' plan to introduce folk practices into the everyday lives of Hungarian citizens and confirms their idea that such activities can lead to empathy and consequent political effects. Yet, while Györffy's theory also assumes that the content of Hungarianness is derived from contact with a timeless folk, we have seen that the folk with which dance house revivalists are occupied is conceived quite differently from that about which Györffy wrote. Dance house practices reify "the folk" even while affording it a meaning reflecting contemporary political and economic conditions. Indeed, the agricultural population in Hungary is of little concern to revivalists. Finally, while populist (népi) activists pursued political goals in tandem with populist "cultivation," the refusal of ideology that characterizes dance house goers does not allow them to recognize political upshots. This commitment to the purity of the spiritual sphere serves to obscure connections with the political sphere. Nevertheless, in this examination we have seen that ethical cultivation may indeed be a powerful element in the process of state formation. Therefore, we must take seriously Györffy's idea that the practice of folk forms, combined with a will to be Hungarian, will produce something - a particular collective memory about Hungarianness - and may lead to social change. Despite a lack of belief in the relationship between ethics and politics among contemporary dance house goers, these individualized practices of what Charles Hirschkind calls ethical self-discipline can cultivate frameworks of sense. Whether these frameworks of sense are evidence of "Hungarianness" is another question.

\section{Notes}

* An earlier version of this paper was presented at the April 2008 symposium at Indiana University entitled the Hungarian Folk Music Revival and Dance House Movement. I would like to thank Ágnes Fülemile for inviting me to give this paper at the symposium and László Felföldi, László Kelemen, and Carol Silverman for comments on the presentation. I am indebted to Banu Karaca and Csilla Kalocsai for their close readings of and commentary on the manuscript.

1 The term nép is analogous with the German term Volk, and therefore reflects the same tensions between class and ethnic usages. The English term folk has lost its class and ethnic sense, retaining only the agricultural meaning. Reflecting these tensions and the breadth with which the term nép has been employed, translation into English can be problematic. In this paper I will at times use the term nép and its adjectival form, népi to illustrate both continuities and discontinuities in conceptualizations and uses of the terms.

2 Herder made specific reference to Hungary in Ideen zur Philosophie der Geschichte der Menschheit, in which he prophesized that, surrounded by a sea of Slavic and Germanic peoples, the Hungarian language, and thus the Hungarian nationality itself, was destined to disappear. 
3 While based on the literary debates between the two groups, many define "populists," cultural and political advocates for the folk, as having been in opposition with urbanists, who represented an urbanite worldview and advocated its place in Hungarian society (and quite often espoused social democratic political views), it is important to note that in the interwar period both groups stood in opposition to the Christian National Government's feudal ideology of limited citizenship.

4 I am indebted to Corrigan and Sayer, Philip Abrams, and Charles Tilly for this vision of state formation, civil society and social movements.

5 The fact that Borbándi's book translates as "The Hungarian Populist Movement" reflects the prevalence of agrarian "populist" movements in East Central Europe in the 19th and 20th centuries. This is interesting, as dance house participants quite freely refer to themselves as népi, the term that translates to populist in the interwar period, and prompts us to examine the historical dimensions of the word. See Held 1996 and Pirie 1997 for discussions of East Central European populisms.

6 Please see page 12, paragraph 2 revivalists refer to themselves as népi, but would not be happy with populist as a translation for their behaviors or stances. This reflects the tension bwteen understanding the term "népi mozgalom" as populist movement or folk movement.

7 In his now often quoted text, T. H. Marshall disaggregated citizenship into three elements: the political, civil and social. He defines political rights as the "right to participate in the exercise of political power as a member of a body invested with political authority or as an elector of the members of such a body," civil rights as those "necessary for individual freedom-liberty of person, freedom of speech, thought and faith, the right to own property and to conclude valid contracts, and the right to justice [that is] the right to defend and assert all one's rights on terms of equality with others and by due process of law", and political rights as "the right to participate in the exercise of political power as a member of the body invested with political authority or as an elector of the members of such a body". He defines social rights as "the right to a modicum of economic welfare and security [and the] right to share to the full in the social heritage and to live the life of a civilized being according to the standards prevailing in society." (T. H. Marshall, quoted in Seligman 1992, 113-114). This aggregate approach to citizenship allows us to view citizenship, and thus, state formation dynamically.

8 Journalist György Oláh published a book entitled Három millió koldus in 1928. The term was adopted in public debate and literature to refer to the poorest stratum of peasant society (Borbándi 1989, 58; Vitányi, personal communication).

9 The term polgár (derived from Burgher) was used to refer to the bourgeoisie and often used as a gloss for Jew (Borbándi 1989, 33, 48; Mócsy 1983).

10 For a detailed discussion of the interrelations and differences between these activities, see Taylor 2008 and Borbándi 1989.

11 Borbándi insists that style alone was not enough to make one populist or urbanist (Borbándi 1989, 195).

12 It was Györffy's good friend Pál Teleki, Minister of Culture at the time, who made it possible for the Institute to open, but who also berated the researchers for what he saw as bad science and an affront to his class (Borbándi, 239-240).

13 Even Andrásfalvy $(1991,161)$ points this out after he insists on the cultural meaning of middle class.

14 We can find folk writers adopting anything along the spectrum of far right to far left stances in this period, while still usually not supporting the Christian National view. Populist activists, however, did work within government institutions, where they believed they could influence the direction of events.

15 Féja was one of the organizers of the March Front and a NÉKOSZ activist. 
16 The main founders of the party were Imre Kovács, Pál Szabó, Ferenc Erdei, Ferenc Farkas, Péter Veres (Borbándi 1989, 323-326).

17 István Deák challenges the popular view of the Populist Writers as oppressed by the Communists. He argues that they were actually favored by the Party leadership. Because they were not Jews, they were seen as "likely to serve as a bridge between the Party leadership and the people” (Deák 1999, 56).

18 Dance house events are held daily in Budapest. They are held several times a week in provincial cities and towns, and hardly at all in rural areas of Hungary. Dance house "folkdance as mother tongue" techniques have become standard training for performing folkdancers, who may or may not attend dance house events.

19 Melucci (1988) used the phrases framework of sense and community of sense interchangeably. In this work I use framework of sense to represent the common set of senses and sensibilities discussed in this chapter, while I reserve "community of sense" for those moments in which this network of dance house goers can be seen to congeal into a community in relation to the formal political process.

20 See Hofer (1980) for a discussion of the role played by the discipline of ethnography in East European nation building.

21 It was called Népművészeti Intézet (Institute for Folk Art) from 1951-1957, Népművelődési Intézet (Institute for People's Culture) from 1957-1986, Országos Közmüvelődési Központ (National Center for Public Cultivation) until 1992, and the Hungarian Institute for Culture since then. In 2001 an independent Institution (also state funded) emerged from the departments dealing with folk art. This Institution, Heritage House, continues to share a building with the Institute.

22 There was some precedent for this, as the Social Democratic party had long used the term nép to represent "the people."

\section{References}

Andrásfalvy, Bertalan (1991) “Györffy István programja a népi müveltség elemeinek össztársadalmi elterjesztésére” in Népi kultúra és nemzettudat, ed. Tamás Hofer (Budapest: Magyarságkutató Intézet).

Balassa, Iván (1993) “Györffy István” in István Györffy, A néphagyomány és a nemzeti müvelödés (Debrecen: A Györffy István Néprajzi Egyesület).

Bartók, Béla (1976) "The Influence of Peasant Music on Newer Composed Music" in Béla Bartók, Essays ed. Benjamin Suchoff, NY Bartók Archive Studies in Musicology 8. (New York: St Martin's Press).

Borbándi, Gyula (1989) A magyar népi mozgalom (Budapest: Püski Kiadó).

Brubaker, Rogers - Feischmidt, Margit - Fox, Jon - Grancea, Liana (2006) Nationalist Politics and Everyday Ethnicity in a Transylvanian Town (Princeton: Princeton University Press).

Burger, Hannalore (2003) "Language Rights and Linguistic Justice in the Education System of the Habsburg Monarchy" (Unpublished paper given at Seminar entitled Official and Scholastic Language in Austria and in Multilingual Areas at the Institute for Central European Cultural Encounters, Gorizia, Italy.)

Chatterjee, Partha (1993) The Nation and its Fragments (Princeton: Princeton University Press).

Chen, Cheng (2003) "The Roots of Illiberal Nationalism in Romania: A Historical Institutionalist Analysis of the Leninist Legacy" in East European Politics and Societies 17(2), 166-201. 
Corrigan, Philip (1994) "State Formation" in Everyday Forms of State Formation, eds. Joseph Gilbert and Daniel Nugent (Durham: Duke University Press).

Deák, István (1999) “On the Leash” in Hungarian Quarterly XL (156).

Eagleton, Terry (1990) The Ideology of the Aesthetic (London: Blackwell 1990).

Election Profile for Hungary, "Election Guide, Electronic Document", http://www.electionguide. org/election.php?ID=297, accessed February, 2005.

Elias, Norbert $(1939,1994)$ The Civilizing Process (Oxford: Blackwell).

Györffy, István (1993) A néphagyomány és a nemzeti müvelödés (Debrecen: A Györffy István Néprajzi Egyesület).

Halbwachs, Maurice (1992) On Collective Memory. Ed., translator, Lewis A. Coser (Chicago: University of Chicago Press).

Halmos, Béla (1994) "The History of the Táncház Movement” in Explorations in Finnish and Hungarian Folk Dance Music and Dance Research, Volume I. Eds. Luukola and Hannu Varpu (Kaustinen, Finland: The Folk Music Institute).

Halmos, Béla (2000) "The Táncház Movement” in Hungarian Heritage 1.

Held, Joseph (1996) ed., Populism in Eastern Europe: Racism, Nationalism and Society, Eastern European Monographs No CDXL (Boulder, CO: Eastern European Monographs).

Hirsch, Eric (1997) "Voices from the Black Box: Folk Song, Boy Scouts and the Construction of Folk Nationalist Hegemony in Hungary, 1930-1944" in Antipode 29/2(1997), 197-215.

Hirschkind, Charles (2001) "The Ethics of Listening: Cassette Sermon Audition in Contemporary Egypt" in American Ethnologist 38/3.

Hofer, Tamás (1980) "Ethnic Symbols from the Elements of Peasant Culture" in Diversity and Conflict in Eastern Europe, Peter Sugar, ed. (Oxford).

Kann, Robert A. - David, Zdenek V. (1984) The Peoples of the Eastern Hapsburg Lands, 1856-1918 (Seattle: University of Washington Press).

Kürti, László (2002) Youth and the State in Hungary: Capitalism, Communism and Class (London: Pluto).

Martin, György (1981) "Beszélgetés Martin Györggyel az új folklórhullám és néptáncmozgalom előzményeiről” in Kultúra és közösség 81/4, 42-52.

Melucci, Alberto (1988) "Social Movements and the Democratization of Everyday Life" in Civil Society and the State, ed. John Keane (London: Verso).

Mocsy, István I. (1983) The Effects of World War 1: Hungarian Refugees and Their Impact on Hungary's Domestic Politics, 1918-1921 (New York: Columbia University Press).

New York Times, "Hungary-Rumania Rift Unresolved" New York Times, September 1(1988).

Olick, Jeffrey K. - Robbins, Joyce (1998) "Social Memory Studies: From 'Collective Memory' to the Historical Sociology of Mnemonic Practices" in Annual Review of Sociology 24, 105-40.

Pálfi, Csaba (1970) “A Gyöngyösbokréta története” in Tánctudományi Tanulmányok 1969-1970. eds. Zoltán Dienes and László Maácz (Budapest: A Magyar Táncmúvészek Szövetsége Tudományos Tagozata).

Pirie, Paul (1997) "Review of Joseph Held, ed. Populism in Eastern Europe: Racism, Nationalism and Society" in Slavic and East European Journal 41/3, 525-527.

Renwick, Alan (2006) "Anti-Political or Just Anti-Communist? Varieties of Dissidence in East-Central Europe and Their Implications for the Development of Political Society" in East European Politics and Societies 20/2, 286-318.

Ronström, Owe (1998) Revival in Retrospect. The Folk Music and Dance Revival (European Centre for Traditional Culture, Bulletin IV).

Sebő, Ferenc (1976) Semmi újat találtunk ki - Beszélgetés Sebő Ferenccel. Kritika 77/2: 4-6. 
